\title{
Differentiation of Pluripotent Stem Cells into Hypothalamic and Pituitary Cells
}

\author{
Hidetaka Suga \\ Department of Endocrinology and Diabetes, Nagoya University Hospital, Nagoya, Japan
}

\section{Key Words}

Hypothalamus · Pituitary · Embryonic stem cells .

Differentiation · SFEBq method

\begin{abstract}
The hypothalamic-pituitary system is essential to maintain life and control systemic homeostasis, but it is negatively affected by various diseases, leading to serious symptoms. Embryonic stem (ES) cells differentiate into neuroectodermal progenitors when cultured as floating aggregates under serum-free conditions. Recently, our colleagues have shown that strict removal of exogenous patterning factors during early differentiation steps induced efficient generation of rostral hypothalamic-like progenitors from mouse ES cell-derived neuroectodermal cells. The use of growth factor-free chemically defined medium was critical for this induction. The ES cell-derived hypothalamic-like progenitors generated rostral-dorsal hypothalamic neurons, especially magnocellular vasopressinergic neurons that release the hormone upon stimulation. Subsequently, we reported efficient self-formation of 3-dimensional adenohypophysis tissues in aggregate cultures of mouse ES cells. The ES cells were stimulated to differentiate into nonneural head ectoderm and hypothalamic neuroectoderm in adjacent layers within the aggregate and then treated with hedgehog. Self-organization of Rathke's
\end{abstract}

pouch-like structures occurred at the interface of the two epithelia, as observed in vivo, and various endocrine cells including corticotrophs and somatotrophs were subsequently produced. The corticotrophs efficiently secreted adrenocorticotropic hormone in response to corticotropin-releasing hormone. Furthermore, when engrafted in vivo, these cells rescued the systemic glucocorticoid level in hypopituitary mice. Our present research aims are to prepare hypothalamic and pituitary tissues from human induced pluripotent stem cells and establish effective transplantation techniques with clinical applications. To replicate the complex and precise control of the hypothalamic-pituitary system, regenerative medicine using pluripotent cells may be a hopeful option.

(c) 2014 S. Karger AG, Basel

\section{Introduction}

The hypothalamus and adenohypophysis maintain physiological homeostasis by controlling the endocrine system. Therefore, they are essential for the regulation of vital functions. Owing to many studies, their development and function have been gradually elucidated, but their regeneration remains largely unclear.

Recently, somatic stem cells have been recognized as a major source of tissue maintenance and regeneration. In

\section{KARGER 125\%}

(c) 2014 S. Karger AG, Base

0028-3835/14/1011-0018\$39.50/0

E-Mail karger@karger.com

www.karger.com/nen 
2005, it was reported that somatic stem cells exist in the adenohypophysis [1]. There has been much debate about their functions during early postnatal pituitary maturation [2-6], after pituitary damage [7-9], and in pituitary tumorigenesis [10-13]. Therefore, it is necessary to accumulate scientific knowledge concerning pituitary stem cells.

In addition to somatic stem cells, there have been many studies on embryonic stem (ES) cells and induced pluripotent stem (iPS) cells. These pluripotent stem cells have a self-renewal property and pluripotent differentiation ability. Therefore, they have attracted attention as a cell source for differentiated tissues in clinical applications.

Here, we review the reports of successful differentiation induction of the hypothalamus [14] and adenohypophysis [15] from mouse ES cells using 3-dimensional culture.

\section{A Need for Hypothalamus and Adenohypophysis Regenerative Medicine}

The hypothalamus and adenohypophysis are adjacent tissues, and they function as the center of endocrine systems. Upon their dysfunction, patients present with various systemic symptoms. The current treatment is mainly hormone replacement therapy, but various factors can complicate the proper dose. The difficulty is that drug administration cannot precisely mimic the circadian or stress-induced change of hormone requirements. For example, we have reported that some patients with central diabetes insipidus show unstable serum $\mathrm{Na}$, resulting in a poor prognosis [16]. Such instability is caused by the lack of positive and negative control systems, which is characteristic of hormone-producing cells. Thus, there are many prospects for pituitary regenerative medicine.

\section{Mouse ES Cells}

The establishment of mouse ES cells contributed considerably to the advancement of biology and medicine by pluripotent stem cells. In 1981, Evans and Kaufman [17] succeeded in establishing mouse ES cells from the inner cell mass of mouse blastocyst-stage embryos. Various knockout and knockin mice have been established using genetically modified ES cells, which have contributed to our understanding of gene functions $[18,19]$.

Differentiation of Pluripotent Stem Cells into Hypothalamic and Pituitary Cells
There are two main reasons for using mouse rather than human ES cells in our recent research. One reason is the short developmental period. The duration of mouse fetal development is about 20 days, which is much shorter than that of humans. Therefore, mouse ES cells are suitable to establish novel differentiation methods through many trial-and-error processes. Another reason is the similarity between mouse and human cells. For example, a retina differentiation method from human ES cells [20] was established on the basis of the previous report using mouse ES cells [21]. They resemble each other basically, but the human ES cell differentiation method is modified in little details. The fundamental processes of mouse ES cells appear to be applicable to human ES cells.

\section{Embryology of the Pituitary}

The adenohypophysis, corresponding to the anterior pituitary gland, contains several types of endocrine cells that secrete factors including adrenocorticotropic hormone $(\mathrm{ACTH})$, growth hormone $(\mathrm{GH})$, prolactin, thyroid-stimulating hormone, luteinizing hormone, and follicle-stimulating hormone. The posterior pituitary gland consists of axons and terminals of hypothalamic neurons, i.e., vasopressin and oxytocin neurons. During early development, the adenohypophysis anlage originates as a placode in the nonneural ectoderm adjacent to the anterior neural plate (fig. 1a). Both the adenohypophysis placode and hypothalamic anlage interact with each other. Accordingly, the thickened placode invaginates and subsequently detaches from the oral ectoderm to form a hollowed vesicle named 'Rathke's pouch' [22] (fig. 1a).

Fig. 1. a Mouse pituitary development. b In vitro induction of Rathke's pouches and subsequent generation of ACTH+ cells. c In vitro release from mouse ES-derived ACTH+ cells. Among releasing factors, CRH most efficiently induced ACTH secretion. Pretreatment with hydrocortisone suppressed the $\mathrm{CRH}$-stimulated ACTH secretion from aggregates. TRH $=$ Thyrotropin-releasing hormone; GHRH = growth hormone-releasing hormone; LHRH = luteinizing hormone-releasing hormone; $\mathrm{F}$ = glucocorticoid pretreatment. d Effects of ectopic transplantation. All these mice, except for wild-type (WT) mice, received hypophysectomy, and their hypopituitarism was confirmed by $\mathrm{CRH}$ loading. The values shown on the graphs represent the mean \pm SEM. $\mathrm{S}^{+} \mathrm{D}^{+}=$Aggregates treated with SAG and DAPT; $\mathrm{S}^{-} \mathrm{D}^{-}=$neither SAG nor DAPT treatment. ${ }^{*} \mathrm{p}<0.05$; $^{* *} \mathrm{p}<0.01{ }^{* * *} \mathrm{p}<0.001$ (from Suga et al. [15], modified version).

(For figure see next page.)

Neuroendocrinology 2015;101:18-24 19 

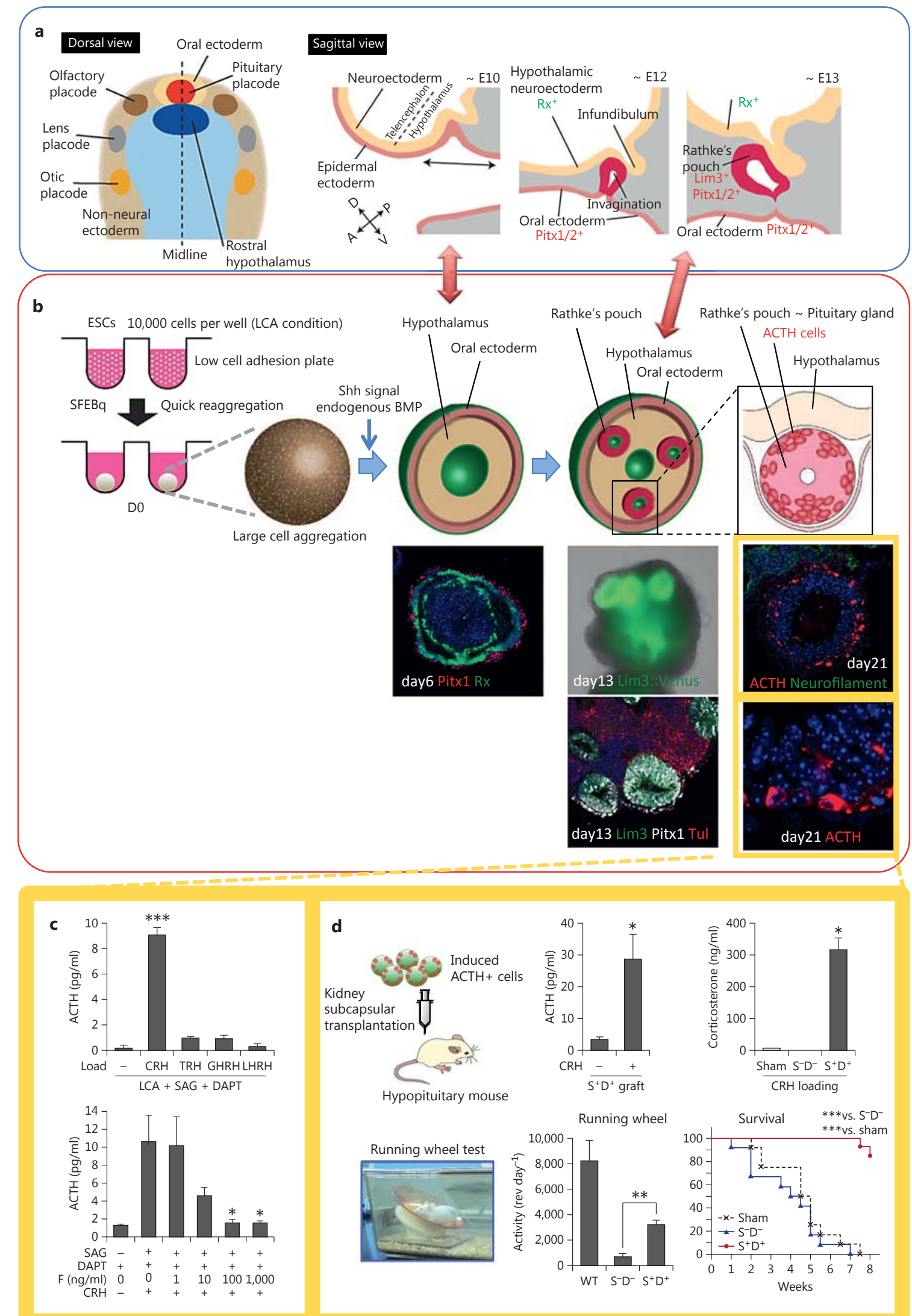

1 


\section{3-Dimensional Culture of ES Cells}

Our colleagues established a 3-dimensional culture method for ES cells called 'serum-free culture of embryoid body-like aggregates with quick reaggregation' (SFEBq) $[23,24]$. The culture method is suitable for the induction of various ectodermal derivatives from ES cells. Using the SFEBq method, mesencephalic dopamine neurons $[25,26]$, cortex neurons $[24,27,28]$, the optic cup $[21,29,30]$, and cerebellar neurons [31] have been generated from mouse and human ES cells.

In SFEBq culture, ES cell aggregates show self-organization [32] and spontaneous formation of a highly ordered structure or patterning from elements without prepatterning.

\section{Two-Layer Formation in Culture}

It is known that Rathke's pouch forms as a result of an interaction between the hypothalamus and the neighboring oral ectoderm [22]. To recapitulate embryonic pituitary development, we aimed to coinduce these two tissues within one ES cell aggregate.

In a previous study, our colleagues succeeded in inducing hypothalamic tissues from mouse ES cells [14]. During early embryonic development, the hypothalamus position in the cerebral nervous systems is characterized by the most rostral and most ventral part in the neural plate (fig. 1a). Hypothalamic differentiation is inhibited by many signals in differentiation medium. Hence, growth factor-free chemically defined medium has been applied to induce hypothalamic differentiation at high efficiency [14]. Mouse ES cells can be induced to differentiate into the rostral hypothalamus when cultured as floating aggregates by the SFEBq method in growth factor-free chemically defined medium.

Based on this finding, we attempted to shift the positional information slightly so that the oral ectoderm coexisted with hypothalamic tissues simultaneously [15]. As shown in figure 1a (dorsal view), the oral ectoderm is generated from the rostral and midline part adjacent to the hypothalamic lesion in mouse embryo. Therefore, the rostral and midline shifting information seemed important for the mouse ES cell aggregates in the SFEBq culture. We tested many culture conditions that are known to affect early ectodermal patterning. Finally, we found two conditions that efficiently induce the oral ectoderm. One condition was the addition of bone morphogenetic protein 4 (BMP4). However, treatment with $0.5 \mathrm{nM}$ BMP4

Differentiation of Pluripotent Stem Cells into Hypothalamic and Pituitary Cells strongly inhibited hypothalamic neuron differentiation instead of inducing oral ectodermal differentiation. The other condition was high-density cell aggregation $(10,000$ cells per aggregate instead of 3,000 in SFEBq culture), which we refer to as large cell aggregation (LCA). In LCA culture, both the oral ectoderm and hypothalamic tissues coexist within one aggregate.

LCA culture allows the formation of the oral ectoderm epithelium on the surface of mouse ES cell aggregates and hypothalamic neural tissue in the inner layer adjacent to the oral ectoderm (fig. 1b). Treatment with a BMP4 antagonist, dorsomorphin, suppresses the generation of the oral ectoderm. Quantitative polymerase chain reaction analyses revealed significantly higher internal BMP4 expression in LCA aggregates. Moreover, Koehler et al. [33] has succeeded to differentiate the otic placode that belongs to the head and oral ectoderm by BMP treatment of mouse ES cells. In general, early exposure to BMP4 is known to favor nonneural ectodermal differentiation at the cost of neural differentiation in mouse ES cell culture [23, 34-36]. Taken together, appropriate BMP4 expression appears to be important for head ectodermal induction.

\section{Self-Formation of Rathke's Pouch}

In the developing embryo, Rathke's pouch forms on the midline of the head ectoderm. Sonic hedgehog (Shh) is expressed in the ventral diencephalon and oral ectoderm but is excluded from the invaginating Rathke's pouch [22,37]. Rathke's pouch receives Shh signals from the neighboring tissues in vivo, and Shh is known to the midline signal, and cells pattern themselves in response [22]. Therefore, we added the smoothened agonist SAG as a strong Shh signal to the differentiation medium of mouse ES cell aggregates in vitro. On day 13 , multiple oval structures were formed in the SAG-treated LCA SFEBq aggregates (fig. 1b). The vesicles were situated between the oral ectoderm and hypothalamic neurons. Lim3 (the formal gene name is Lhx3) expression indicated that the vesicles were similar to Rathke's pouch. These Lim3+ tissues appeared as a thick epithelium on the surface and then invaginated and finally formed hollowed vesicles. The length of the major axis was about $200 \mu \mathrm{m}$, which is almost equal to the size of the embryonic Rathke's pouch.

The interactions between the oral ectoderm and hypothalamic neurons appear to be critically important. Neither isolated surface ectoderm alone nor isolated hypothalamic tissues alone formed Lim3+ pouches. Only in cases reassembling the two divided components, Lim3+ 
expression recovered to some extent [15]. These findings demonstrate self-formation of Rathke's pouch in mouse ES cell aggregates.

\section{Differentiation into Hormone-Producing Endocrine Cells}

During pituitary development in the embryo, Lim3+ pituitary progenitors become committed to several lineages, i.e., corticotroph, somatotroph, lactotroph, thyrotroph, gonadotroph, and melanotroph lineages. Among them, the ACTH-producing corticotroph lineage expresses the transcription factor Tbx19 before ACTH expression. It is known that Notch signaling inhibits Tbx19 expression [38-40]. Therefore, we evaluated the effect of a Notch inhibitor, DAPT. As a result, DAPT treatment increased Tbx19 expression in SAG-treated LCA SFEBq aggregates. A substantial number of ACTH+ cells appeared in the Tbx19+ lesion (fig. 1b). Without DAPT treatment, corticotroph differentiation efficiency was down, and other lineages did not appear.

Previous reports have shown that canonical Wnt signaling promotes Pit 1 expression [41-43]. Consistent with this finding, the treatment of a Wnt agonist, BIO, increased Pit 1 expression, resulting in subsequent $\mathrm{GH}+$ and prolactin-positive cell differentiation.

Head mesenchyme has been suggested to promote pituitary development in vivo [44]. Therefore, we applied the conditioned medium of PA6 stromal cells to SAGtreated LCA SFEBq aggregates. As a result, we successfully induced luteinizing hormone-, follicle-stimulating hormone-, and thyroid-stimulating hormone-positive cells. But the factors supplying PA6 remain elusive.

Lim3 is essential for these hormone-producing lineages. To suppress Lim3 expression in differentiating mouse ES cells, we utilized the Tet-inducible shRNA expression lentivirus vector system (a kind gift from Hiroyuki Miyoshi at RIKEN BioResource Center). Knockdown of Lim3 inhibits subsequent differentiation into hormone-producing cells. These results demonstrate the competence of ES cell-derived pituitary progenitors to generate multiple endocrine lineages in vitro.

\section{Functionality of Induced ACTH+ Cells}

Positive and negative regulation by exogenous stimuli is characteristic of endocrine cells. To investigate in vitro functionality, we chose induced $\mathrm{ACTH}+$ cells for the evaluation because they are the most efficiently generated by the SAG-treated LCA SFEBq method.

After 10 min of stimulation by corticotropin-releasing hormone (CRH), substantial amounts of ACTH were secreted from SAG-treated LCA SFEBq aggregates in vitro (fig. 1c). The secreted ACTH level was almost the same as the concentration in mouse peripheral blood. ACTH secretion from the pituitary gland is negatively regulated by the downstream hormone glucocorticoid. Consistent with this control principle, the in vitro ACTH secretion by $\mathrm{CRH}$ stimulation was suppressed by glucocorticoid pretreatment (fig. 1c). Similarly to endocrine systems in vivo, these data demonstrate that mouse ES cell-derived $\mathrm{ACTH}+$ cells respond to both positive and negative regulators.

\section{Effect of Transplantation into Hypophysectomized Model Animals}

Finally, we evaluated the effect of transplantation of these induced ACTH+ cells. Because of the technical difficulty, we chose ectopic transplantation, especially into the kidney subcapsule, instead of orthotopic transplantation into the sella turcica. At 1 week after transplantation, blood ACTH levels showed a slight but significant increase. CRH loading induced substantial elevation in blood ACTH levels. A downstream glucocorticoid hormone, corticosterone, was also significantly increased, indicating that ACTH from the graft sufficiently induced the downstream hormone.

Even without CRH loading, the basal levels of ACTH were higher. Importantly, the corticosterone levels were also increased, suggesting that this partial recovery of blood ACTH has a moderate but biologically significant effect (note that $\mathrm{ED}_{50}$ of the ACTH receptor MC2R for glucocorticoid production is around $9 \mathrm{pg} / \mathrm{ml}$ ) [45]. In accordance with this idea, the treated hypophysectomized mice displayed higher spontaneous locomotor activities and survived significantly longer (fig. 1d).

Although $\mathrm{CRH}$, secreted from the hypothalamus, should be diluted in the peripheral site, human ES cellderived pituitary tissues rescued survival and activities, suggesting that the basal secretion from these tissues was sufficient to have those effects.

These findings show that induced ACTH+ cells derived from mouse ES cells act as endocrine tissues and that regenerative medicine for pituitary dysfunction is feasible. 


\section{Future Perspectives}

Although stem cell-based therapeutics have high expectations for the treatment of diabetes mellitus, little attention has been drawn to the possibility of regenerative medicine for hypothalamus-hypophyseal dysfunctions. Panhypopituitarism is a major category of endocrinological diseases.

There have been several studies that generated the pituitary hormone-producing cells from mouse ES cells [46, 47]. All of them used 3 -dimensional cultures, for example, the hanging-drop method. It seems to indicate that 3-dimensional culture is suitable for the recapitulation of embryonic development. Although their studies played a pioneering role, the functionality of the derived pituitary cells has not been confirmed. Our recent study has demonstrated that ES cell-derived ACTH-producing cells function even after ectopic transplantation. This finding raises the possibility of relatively simple grafting of artificial ES cellderived pituitary tissues into a peripheral site, which function effectively if their hormone secretion can be controlled extrinsically by releasing factors or their small molecule agonists. However, this ectopic transplantation is not perfect because physiological CRH released from the hypothalamus does not affect these grafts directly. Orthotopic transplantation of hormone-producing cells that are controlled by positive and negative regulators can be one of the candidates for complete therapy in the future.

Current hormone replacement therapy cannot mimic the precise control of hormone production. For example, as for patients with ACTH deficiency, the oral administration dosage of cortisol fluctuates from 15 to $300 \mathrm{mg}$ / day according to daily stress. In the case of shortage, the patient faces major challenges to survive because of adrenal failure. If the level of replacement is too high, patients suffer from obesity, diabetes mellitus, hypertension, osteoporosis, mental disorder, or increased susceptibility to infection. Successful generation and transplantation of functional pituitary endocrine cells conceptually opens new avenues for the application of pluripotent stem cells to a wide range of nondiabetic endocrine diseases.

For the future clinical use, what we need next is the establishment of a differentiation method from human pluripotent stem cells. Recent research has shown successful differentiation into pituitary cells from human ES cells [48]. The authors did not use 3-dimensional but 2-dimensional monolayer culture. Both ACTH and GH secretion was confirmed. It is the first and striking report, but the maturation procedure seems to require in vivo transplantation at least partly. Positive or negative regulation remains to be explored.

In future studies, it will be challenging to recapitulate the entire anterior pituitary gland containing all endocrine components in 3-dimensional cultures of human ES or iPS cells and use such artificial pituitary tissues for orthotopic transplantation into the sella of a large mammal. To achieve this long-term goal, further studies are needed. There are still many problems to be solved before pituitary regenerative medicine can be transferred to clinical use.

\section{References}

1 Chen J, Hersmus N, Van Duppen V, Caesens P, Denef C, Vankelecom H: The adult pituitary contains a cell population displaying stem/progenitor cell and early embryonic characteristics. Endocrinology 2005; 146: 3985-3998.

-2 Fauquier T, Guérineau NC, McKinney RA, Bauer K, Mollard P: Folliculostellate cell network: a route for long-distance communication in the anterior pituitary. Proc Natl Acad Sci USA 2001;98:8891-8896.

3 Kikuchi M, Yatabe M, Kouki T, Fujiwara K, Takigami S, Sakamoto A, Yashiro T: Changes in $\mathrm{E}$ - and $\mathrm{N}$-cadherin expression in developing rat adenohypophysis. Anat Rec (Hoboken) 2007;290:486-490.

-4 Chen J, Gremeaux L, Fu Q, Liekens D, Van Laere S, Vankelecom H: Pituitary progenitor cells tracked down by side population dissection. Stem Cells 2009;27:1182-1195.

Differentiation of Pluripotent Stem Cells into Hypothalamic and Pituitary Cells
5 Gremeaux L, Fu Q, Chen J, Vankelecom H: Activated phenotype of the pituitary stem/ progenitor cell compartment during the early-postnatal maturation phase of the gland. Stem Cells Dev 2012;21:801-813.

-6 Mollard P, Hodson DJ, Lafont C, Rizzoti K, Drouin J: A tridimensional view of pituitary development and function. Trends Endocrinol Metab 2012;23:261-269.

-7 Luque RM, Lin Q, Córdoba-Chacón J, Subbaiah PV, Buch T, Waisman A, Vankelecom H, Kineman RD: Metabolic impact of adultonset, isolated, growth hormone deficiency (AOiGHD) due to destruction of pituitary somatotropes. PLoS One 2011;6:e15767.

-8 Fu Q, Gremeaux L, Luque RM, Liekens D, Chen J, Buch T, Waisman A, Kineman R, Vankelecom H: The adult pituitary shows stem/progenitor cell activation in response to injury and is capable of regeneration. Endocrinology 2012;153:3224-3235.
\9 Langlais D, Couture C, Kmita M, Drouin J: Adult pituitary cell maintenance: lineage-specific contribution of self-duplication. Mol Endocrinol 2013;27:1103-1112.

10 Gaston-Massuet C, Andoniadou CL, Signore M, Jayakody SA, Charolidi N, Kyeyune R, Vernay B, Jacques TS, Taketo MM, Le Tissier P, Dattani MT, Martinez-Barbera JP: Increased Wingless (Wnt) signaling in pituitary progenitor/stem cells gives rise to pituitary tumors in mice and humans. Proc Natl Acad Sci USA 2011;108:11482-11487.

11 Andoniadou CL, Gaston-Massuet C, Reddy R, Schneider RP, Blasco MA, Le Tissier P, Jacques TS, Pevny LH, Dattani MT, MartinezBarbera JP: Identification of novel pathways involved in the pathogenesis of human adamantinomatous craniopharyngioma. Acta Neuropathol 2012;124:259-271. 
\12 Garcia-Lavandeira M, Saez C, Diaz-Rodriguez E, Perez-Romero S, Senra A, Dieguez C, Japon MA, Alvarez CV: Craniopharyngiomas express embryonic stem cell markers (SOX2, OCT4, KLF4, and SOX9) as pituitary stem cells but do not coexpress RET/GFRA3 receptors. J Clin Endocrinol Metab 2012;97:E80E87.

-13 Li H, Collado M, Villasante A, Matheu A, Lynch CJ, Cañamero M, Rizzoti K, Carneiro C, Martínez G, Vidal A, Lovell-Badge R, Serrano M: p27(Kip1) directly represses Sox2 during embryonic stem cell differentiation. Cell Stem Cell 2012;11:845-852.

$\checkmark 14$ Wataya T, Ando S, Muguruma K, Ikeda H, Watanabe K, Eiraku M, Kawada M, Takahashi J, Hashimoto N, Sasai Y: Minimization of exogenous signals in ES cell culture induces rostral hypothalamic differentiation. Proc Natl Acad Sci USA 2008;105:11796-11801.

$\checkmark 15$ Suga H, Kadoshima T, Minaguchi M, Ohgushi M, Soen M, Nakano T, Takata N, Wataya T, Muguruma K, Miyoshi H, Yonemura S, Oiso Y, Sasai Y: Self-formation of functional adenohypophysis in three-dimensional culture. Nature 2011;480:57-62.

- 16 Arima H, Wakabayashi T, Nagatani T, Fujii M, Hirakawa A, Murase T, Yambe Y, Yamada T, Yamakawa F, Yamamori I, Yamauchi M, Oiso Y: Adipsia increases risk of death in patients with central diabetes insipidus. Endocr J 2014;61:143-148.

$\checkmark 17$ Evans MJ, Kaufman MH: Establishment in culture of pluripotential cells from mouse embryos. Nature 1981;292:154-156.

18 Bernstein A, Breitman M: Genetic ablation in transgenic mice. Mol Biol Med 1989;6:523530.

$\checkmark 19$ Babinet C, Cohen-Tannoudji M: Genome engineering via homologous recombination in mouse embryonic stem (ES) cells: an amazingly versatile tool for the study of mammalian biology. An Acad Bras Cienc 2001;73: 365-383.

20 Nakano T, Ando S, Takata N, Kawada M, Muguruma K, Sekiguchi K, Saito K, Yonemura S, Eiraku M, Sasai Y: Self-formation of optic cups and storable stratified neural retina from human ESCs. Cell Stem Cell 2012;10:771785.

21 Eiraku M, Takata N, Ishibashi H, Kawada M, Sakakura E, Okuda S, Sekiguchi K, Adachi T, Sasai Y: Self-organizing optic-cup morphogenesis in three-dimensional culture. Nature 2011;472:51-56.

-22 Zhu X, Gleiberman AS, Rosenfeld MG: Molecular physiology of pituitary development: signaling and transcriptional networks. Physiol Rev 2007;87:933-963.

-23 Watanabe K, Kamiya D, Nishiyama A, Katayama T, Nozaki S, Kawasaki H, Watanabe Y, Mizuseki K, Sasai Y: Directed differentiation of telencephalic precursors from embryonic stem cells. Nat Neurosci 2005;8:288-296.
24 Eiraku M, Watanabe K, Matsuo-Takasaki M, Kawada M, Yonemura S, Matsumura M, Wataya T, Nishiyama A, Muguruma K, Sasai Y: Self-organized formation of polarized cortical tissues from ESCs and its active manipulation by extrinsic signals. Cell Stem Cell 2008;3: 519-532.

25 Kawasaki H, Suemori H, Mizuseki K, Watanabe $\mathrm{K}$, Urano F, Ichinose $\mathrm{H}$, Haruta $\mathrm{M}$, Takahashi M, Yoshikawa K, Nishikawa S, Nakatsuji N, Sasai Y: Generation of dopaminergic neurons and pigmented epithelia from primate ES cells by stromal cell-derived inducing activity. Proc Natl Acad Sci USA 2002; 99:1580-1585.

26 Morizane A, Takahashi J, Shinoyama M, Ideguchi M, Takagi Y, Fukuda H, Koyanagi M, Sasai Y, Hashimoto N: Generation of graftable dopaminergic neuron progenitors from mouse ES cells by a combination of coculture and neurosphere methods. J Neurosci Res 2006;83:1015-1027.

27 Danjo T, Eiraku M, Muguruma K, Watanabe K, Kawada M, Yanagawa Y, Rubenstein JL, Sasai Y: Subregional specification of embryonic stem cell-derived ventral telencephalic tissues by timed and combinatory treatment with extrinsic signals. J Neurosci 2011;31: 1919-1933.

28 Kadoshima T, Sakaguchi H, Nakano T, Soen M, Ando S, Eiraku M, Sasai Y: Self-organization of axial polarity, inside-out layer pattern, and species-specific progenitor dynamics in human ES cell-derived neocortex. Proc Natl Acad Sci USA 2013;110:20284-20289.

29 Ikeda H, Osakada F, Watanabe K, Mizuseki K, Haraguchi T, Miyoshi H, Kamiya D, Honda Y, Sasai N, Yoshimura N, Takahashi M, Sasai $\mathrm{Y}$ : Generation of $\mathrm{Rx}+/ \mathrm{Pax} 6+$ neural retinal precursors from embryonic stem cells. Proc Natl Acad Sci USA 2005;102:11331-11336.

- 30 Osakada F, Ikeda H, Mandai M, Wataya T, Watanabe K, Yoshimura N, Akaike A, Sasai $\mathrm{Y}$, Takahashi M: Toward the generation of rod and cone photoreceptors from mouse, monkey and human embryonic stem cells. Nat Biotechnol 2008;26:215-224.

31 Muguruma K, Nishiyama A, Ono Y, Miyawaki H, Mizuhara E, Hori S, Kakizuka A, Obata K, Yanagawa Y, Hirano T, Sasai Y: Ontogenyrecapitulating generation and tissue integration of ES cell-derived Purkinje cells. Nat Neurosci 2010;13:1171-1180.

32 Sasai Y, Eiraku M, Suga H: In vitro organogenesis in three dimensions: self-organising stem cells. Development 2012;139:41114121.

- 33 Koehler KR, Mikosz AM, Molosh AI, Patel D, Hashino E: Generation of inner ear sensory epithelia from pluripotent stem cells in $3 \mathrm{D}$ culture. Nature 2013;500:217-221.

34 Wilson PA, Hemmati-Brivanlou A: Induction of epidermis and inhibition of neural fate by Bmp-4. Nature 1995;376:331-333.

- 35 Basch ML, Bronner-Fraser M: Neural crest inducing signals. Adv Exp Med Biol 2006;589: 24-31.
Davis SW, Camper SA: Noggin regulates Bmp4 activity during pituitary induction. Dev Biol 2007;305:145-160.

37 Wang Y, Martin JF, Bai CB: Direct and indirect requirements of Shh/Gli signaling in early pituitary development. Dev Biol 2010;348: 199-209.

38 Lamolet B, Pulichino AM, Lamonerie T, Gauthier Y, Brue T, Enjalbert A, Drouin J: A pituitary cell-restricted $\mathrm{T}$ box factor, Tpit, activates POMC transcription in cooperation with Pitx homeoproteins. Cell 2001;104:849859.

39 Zhu X, Zhang J, Tollkuhn J, Ohsawa R, Bresnick EH, Guillemot F, Kageyama R, Rosenfeld MG: Sustained Notch signaling in progenitors is required for sequential emergence of distinct cell lineages during organogenesis. Genes Dev 2006;20:2739-2753.

40 Kita A, Imayoshi I, Hojo M, Kitagawa M, Kokubu H, Ohsawa R, Ohtsuka T, Kageyama R, Hashimoto N: Hes1 and Hes5 control the progenitor pool, intermediate lobe specification, and posterior lobe formation in the pituitary development. Mol Endocrinol 2007;21: 1458-1466.

41 DiMattia GE, Rhodes SJ, Krones A, Carrière C, O'Connell S, Kalla K, Arias C, Sawchenko P, Rosenfeld MG: The Pit-1 gene is regulated by distinct early and late pituitary-specific enhancers. Dev Biol 1997;182:180-190.

42 Olson LE, Tollkuhn J, Scafoglio C, Krones A, Zhang J, Ohgi KA, Wu W, Taketo MM, Kemler R, Grosschedl R, Rose D, Li X, Rosenfeld MG: Homeodomain-mediated beta-catenindependent switching events dictate cell-lineage determination. Cell 2006;125:593-605.

43 Sornson MW, Wu W, Dasen JS, Flynn SE, Norman DJ, O'Connell SM, Gukovsky I, Carrière $\mathrm{C}$, Ryan $\mathrm{AK}$, Miller $\mathrm{AP}$, Zuo L, Gleiberman AS, Andersen B, Beamer WG, Rosenfeld MG: Pituitary lineage determination by the Prophet of Pit-1 homeodomain factor defective in Ames dwarfism. Nature 1996;384:327333.

44 Gleiberman AS, Fedtsova NG, Rosenfeld MG Tissue interactions in the induction of anterior pituitary: role of the ventral diencephalon, mesenchyme, and notochord. Dev Biol 1999;213:340-353.

45 Melmed S: The Pituitary, ed 3. London, Academic Press, 2011, p. 61.

46 Zhao X, Teng R, Asanuma K, Okouchi Y, Johkura K, Ogiwara N, Sasaki K: Differentiation of mouse embryonic stem cells into gonadotrope-like cells in vitro. J Soc Gynecol Investig 2005;12:257-262.

47 Wagner J, Lepore D, Thomas P: Differentiation of mouse embryonic stem cells into growth hormone and prolactin expressing cells in vitro. Mol Cell Endocrinol 2007;273: 68-74.

48 Dincer Z, Piao J, Niu L, Ganat Y, Kriks S, Zimmer B, Shi SH, Tabar V, Studer L: Specification of functional cranial placode derivatives from human pluripotent stem cells. Cell Rep 2013;5:1387-1402. 